\section{Stable Production of Transgenic Pepper Plants Mediated by Agrobacterium tumefaciens}

\author{
Moon Kyung Ko and Hyunchul Soh \\ Kumho Life \& Environmental Science Laboratory (KLESL), Chonnam \\ National University, 1 Oryong-dong, Buk-gu, Gwangju 500-712, Republic \\ of Korea
}

\author{
Kyung-Moon Kim and Young Soon Kim ${ }^{1}$ \\ Kumho Life \& Environmental Science Laboratory (KLESL), Chonnam \\ National University, 1 Oryong-dong, Buk-gu, Gwangju 500-712, Republic \\ of Korea; and Agricultural Plant Stress Research Center (APSRC), Chonnam \\ National University, 300 Yongbong-dong, Buk-gu, Gwangju 500-757, \\ Republic of Korea

\section{Kyunghoan Im \\ Department of Biology, University of Incheon, 177 Dohwa-dong, Nam-gu, Incheon 402-749, Republic of Korea}

Additional index words. Agrobacterium-mediated, cotyledon, GUS, genetic stability, progeny

\begin{abstract}
The aim of this study was to establish a stable transformation method for hot pepper using the hygromycin phosphotransferase (hpt)/hygromycin selection strategy. Explants from aseptic pepper seedlings were inoculated with Agrobacterium tumefaciens carrying pCAMBIA1301. A number of calli were developed on the medium containing hygromycin to discriminate the induction of "false-positive buds," and then shoots were successfully regenerated from the hygromycin-resistant calli. Southern and Northern hybridization analysis indicated that the hpt gene was integrated and expressed in the transgenic pepper plants $\left(T_{0}\right)$ and transmitted to the progeny $\left(T_{1}\right)$ without genetic modification. Most $T_{1}$ progenies derived from self-pollination revealed a 3:1 segregation ratio for hygromycin resistance, indicating that one copy of the T-DNA was integrated into the respective transgenic lines. Both uid $\mathrm{A}$ and $h p t$ genes were stably expressed in the $T_{1}$ generation and coinherited in the progenies. Finally, homozygous progenies were identified in the $T_{1}$ generation of the transgenic peppers, and the homozygous state was maintained in all progenies tested $\left(T_{2}\right)$. The results show the reliability and stability of the

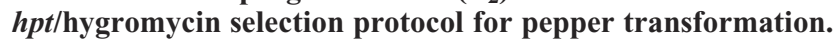

Peppers are important horticultural crops worldwide, and a hot pepper is cultivated extensively in Northeast Asia. Agronomically important traits have been introduced into the pepper by conventional breeding, but the application is currently limited by the lack of genetic resources or by sexual incompatibility between species. Genetic transformation of the plant has become an important alternative for both basic and commercial plant breeding programs. However, genetic engineering of hot pepper has been hindered

\footnotetext{
Received for publication 16 Nov. 2006. Accepted for publication $18 \mathrm{Apr} .2007$.

Moon Kyung Ko and Kyung-Moon Kim contributed equally to this paper.

This research was supported by a grant (code \# M104KG010016-04K0701-01600) from the Crop Functional Genomics Center of the 21st Century Frontier Research Program funded by the Ministry of Science and Technology (MOST) of the Republic of Korea.

${ }^{1}$ To whom reprint requests should be addressed; e-mailyskim2@chonnam.ac.kr.
}

by the difficulty in transforming pepper plants. Only a few papers on Agrobacterium-mediated transformation systems have been published (Cai et al., 2002; Lee et al., 2004; Shin et al., 2002; Zhu et al., 1996), and there have been few reports on the reliable inheritance of transformed genes. Therefore, development of more efficient procedures for Agrobacterium-meditated transformation could facilitate routine production of transgenic pepper lines.

In relation to tissue culture of pepper, initial efforts were concentrated on androgenesis and adventitious regeneration through organogenesis (Dumas de Vaulx et al., 1981; Ebida and Hu, 1993; Phillips and Hubstenberger, 1985). The somatic embryogenesis system was also used for in vitro regeneration in peppers but failed to develop further in some Capsicum varieties (Binzel et al., 1996; Steintiz et al., 2003). In organogenesis, highly morphogenic tissues from seedlings exhibit a higher bud induction response, but shoot elongation was often problematic in whole-plant regeneration (Gunay and Rao, 1978). Multiple shoots could develop directly from the explant surface or indirectly through callus derived from explant tissues (Agrawal et al., 1989). However, direct shoots were often laterally fused into leaf-like structures rather than organized into a shoot bud so that the structure was unable to elongate into a normal shoot (Liu et al., 1990; Wolf et al., 2001). Lee et al. (2004) reported that none of the regenerants from direct shooting turned out to be true transgenic plants. In indirect regeneration, shoot development from callus tissues has rarely occurred. So, despite numerous reports on tissue culture, plant regeneration from cultured pepper explants has been hampered, especially in the genetic engineering of pepper.

In transforming the pepper plant, the use of a suitable selectable marker is very important for the efficient selection of transformed event. The neomycin phosphotransferase II (nptII) gene has been previously used as a selection marker for pepper transformation (Cai et al., 2003; Zhu et al., 1996). However, pepper explants show some intrinsic resistance to kanamycin, as shown in some other crops (Mihalka et al., 2000). This causes poor selection of transformed cells, which results in extremely low transformation efficiency. Therefore, an alternative strategy for strict selection of transformed pepper cells is needed to avoid the growth of untransformed escapes. The hygromycin phosphotransferase ( hpt) gene has been used in crop transformation as a marker to allow stringent selection of the transformed event (Van den Elzen et al., 1985). Thus, in the present study, the reliability of the use of hygromycin as a selection agent was examined and assessed for its efficacy in pepper transformation.

Once transgenic plants have been established, the transgenes should be stably integrated and expressed over generations. However, the expression level and patterns of transgene inheritance vary widely among transformed plants. Factors responsible for transgene instability include the site of integration in the genome, the transgene copy number, transgene rearrangement, transformation system (Agrobacterium-mediated, microprojectile bombardment, or PEG, and so on), the selection strategy, and the plant tissue culture system (Birch, 1997; Walden and Wingender, 1995).

In the present study, we used the hpt gene in pepper transformation as a selectable marker for the first time. Fertile transgenic plants were regenerated from hygromycinresistant callus transformed by Agrobacterium-mediated method. Gene expression and stable inheritance of $h p t$ and uidA genes were also analyzed in advanced generations of transgenic progenies.

\section{Materials and Methods}

Plant material. Seeds of a hot pepper (Capsicum annuum L. cv. Nockkwang) were obtained from a commercial source (Heungong Seed Co. Ltd., Ansung, Korea). The seeds were surface-sterilized in $70 \% \mathrm{EtOH}$ 
$(\mathrm{v} / \mathrm{v})$ for $5 \mathrm{~min}$ and in 30\% commercial bleach [Clorox (Yuhan Clorox, Incheon, Korea)] for $10 \mathrm{~min}$ and then rinsed three times with sterile $\mathrm{ddH}_{2} \mathrm{O}$. The surface-sterilized seeds were placed in a magenta box containing MS (Murashige and Skoog, 1962) medium for germination. The seeds were allowed to germinate in the dark at $25{ }^{\circ} \mathrm{C}$. The cotyledons and hypocotyls from 7-dayold seedlings were excised and used as explants for transformation.

Plant expression vectors and preparation of Agrobacterium tumefaciens. The plasmid vector pCAMBIA1301 (CAMBIA, Clayton Australia), which contains $\beta$-glucuronidase (uidA) and hygromycin phosphotransferase (hpt) genes under the control of the CaMV35S promoter, was transferred into $A$. tumefaciens strain GV3101. Agrobacterium cells harboring pCAMBIA1301 were grown overnight in LB medium supplemented with $50 \mathrm{mg} \cdot \mathrm{L}^{-1}$ of kanamycin monosulfate and 50 $\mathrm{mg} \cdot \mathrm{L}^{-1}$ of rifampicin in a shaking incubator at $28{ }^{\circ} \mathrm{C}$. Cultured Agrobacterium cells were harvested and then diluted with MS medium containing $100 \mu \mathrm{M}$ acetosyringone (AS) to an optical density of 0.3 to 0.5 at $600 \mathrm{~nm}$.

Transformation and regeneration. The explants were inoculated with Agrobacterium cells in suspension for $10 \mathrm{~min}$ and then blotted on sterile filter papers to remove excess bacterial cells. The infected explants were cocultured in semisolid MS medium containing $100 \mu \mathrm{M}$ AS in the dark for $48 \mathrm{~h}$. After cocultivation, explants were washed two to three times with $500 \mathrm{mg} \cdot \mathrm{L}^{-1}$ cefotaxime and transferred onto MS medium supplemented with $3 \%(\mathrm{w} / \mathrm{v})$ sucrose and $0.8 \%(\mathrm{w} / \mathrm{v})$ plant agar, $2 \mathrm{mg} \cdot \mathrm{L}^{-1}$ zeatin (Duchefa, Haarlem, The Netherlands), $0.2 \mathrm{mg} \cdot \mathrm{L}^{-1}$ indolacetic acid (IAA), $20 \mathrm{mg} \cdot \mathrm{L}^{-1}$ hygromycin, and 300 $\mathrm{mg} \cdot \mathrm{L}^{-1}$ cefotaxime. Explants were subcultured onto a fresh medium at 2- to 3-week intervals. For shoot induction, the selected green calli were transferred onto regeneration medium, which was supplemented with 0.05 $\mathrm{mg} \cdot \mathrm{L}^{-1}$ IAA, $2 \mathrm{mg} \cdot \mathrm{L}^{-1}$ zeatin, $10 \mathrm{mg} \cdot \mathrm{L}^{-1}$ hygromycin, and $300 \mathrm{mg} \cdot \mathrm{L}^{-1}$. Plantlets resistant to hygromycin were transferred onto rooting medium containing MS basal salts and $300 \mathrm{mg} \cdot \mathrm{L}^{-1}$ cefotaxime without the selectable agent. All cultures were incubated at $24{ }^{\circ} \mathrm{C}$ under a $16 / 8 \mathrm{~h}$ (light/dark) photoperiod. Plants having well-developed roots were transplanted to a pot in a greenhouse and allowed to grow until they set seeds.

Histochemical and fluorometric $\beta$ Glucuronidase (GUS) assay. $\beta$-Glucuronidase (GUS) activity was histochemically and fluorometrically assayed in plant tissues and organs from transgenic pepper plants. Histochemical staining for GUS activity was based on the method of Jefferson (1987) with a 5-bromo-4-chloro-3-indoyl- $\beta$-glucuronic acid (X-gluc) solution as a substrate. The samples were soaked overnight in X-gluc solution at $37{ }^{\circ} \mathrm{C}$. In addition, fluorometric analysis of GUS activity was carried out in the flower, shoot apex, leaf, stem, and root from transgenic lines with the modification of Jefferson (1987). A $100 \mathrm{mg}$ of plant tissue was homogenized in $1 \mathrm{~mL}$ extraction buffer containing $50 \mathrm{mM} \mathrm{NaPO}_{4}(\mathrm{pH} 7.0), 10 \mu \mathrm{M}$ $\beta$-mercaptoethanol, $10 \mathrm{~mm}$ EDTA, $0.1 \%$ sarcosyl, and $0.1 \%$ Triton X-100. Five microliters of supernatant was reacted in the extraction buffer containing $1 \mathrm{~mm}$ of 4 methyl- $\beta$-D-unibelliferyl glucuronide. The enzymatic reaction was measured by a fluorometer TD-700 (Turner Designs, Sunnyvale, CA) with excitation at $365 \mathrm{~nm}$ and emission at $455 \mathrm{~nm}$. The concentration of protein was determined by the Bradford method (Bradford, 1976).

Progeny analysis by hygromycin resistance (leaf assay in hygromycin solution). Leaf assay in hygromycin solution for the expression of the hpt gene was conducted to distinguish transformed plants from nontransformed plants. Leaf samples from young plants were placed in a 24-well culture plate containing 0.5 $\mathrm{mL}$ of $100 \mathrm{mg} \cdot \mathrm{L}^{-1}$ hygromycin or distilled water. Three leaf disks from a wild-type pepper plant at a similar growth stage were used as a negative control. The leaf disks were placed under light at $25^{\circ} \mathrm{C}$ for 3 to $5 \mathrm{~d}$. The leaf disks resistant to hygromycin remained green, indicating that the hpt gene was successfully integrated and expressed in pepper. In addition, primary transgenic plants $\left(T_{0}\right)$ were self-pollinated and their $\mathrm{T}_{1}$ progeny were germinated in MS medium containing 20 $\mathrm{mg} \cdot \mathrm{L}^{-1}$ hygromycin. The data were then analyzed by $\chi^{2}$ test to determine the number of functional hpt gene loci on the pepper genome. $\mathrm{T}_{2}$ progeny were also tested for hygromycin resistance to identify homogeneity.

Southern and Northern blot analysis. Pepper genomic DNA was isolated by using a DNeasy Plant Mini Kit (Qiagen, Hilden, Germany) as described by the manufacturer. Fifteen micrograms of each DNA sample was digested with HindIII in $50 \mu \mathrm{L}$ of the manufacturer's (NEB, Beverly, MA) buffer overnight and separated on a $0.8 \%(\mathrm{w} / \mathrm{v})$ agarose gel. For blot analysis, DNA was transferred to a Hybond ${ }^{+}$nylon membrane and DNA was fixed to the membrane by ultraviolet crosslinking. Prehybridization was carried out at $65^{\circ} \mathrm{C}$ for $3 \mathrm{~h}$ in Rapid-hyb buffer (Amersham

Table 1. Determination of antibiotic sensitivity on the growth and shoot development of pepper explants on various concentration of antibiotics.

\begin{tabular}{|c|c|c|c|c|c|c|}
\hline \multirow[b]{2}{*}{ Explants $^{\mathrm{z}}$} & \multicolumn{6}{|c|}{ Kanamycin $\left(\mathrm{mg} \cdot \mathrm{L}^{-1}\right)$} \\
\hline & 0 & 50 & 100 & 150 & 200 & 250 \\
\hline \multicolumn{7}{|l|}{ Survived (\%) } \\
\hline Cotyledon & $25(100)^{\mathrm{y}}$ & $23(92)$ & $22(88)$ & $12(48)$ & $0(0)$ & $0(0)$ \\
\hline Hypocotyl & $25(100)$ & $21(84)$ & $14(56)$ & $7(28)$ & $0(0)$ & $0(0)$ \\
\hline \multicolumn{7}{|c|}{ Regenerated (\%) } \\
\hline Cotyledon & $25(100)^{x}$ & $23(92)$ & $22(88)$ & $0(0)$ & $0(0)$ & $0(0)$ \\
\hline Hypocotyl & $25(100)$ & $21(84)$ & $0(0)$ & $0(0)$ & $0(0)$ & $0(0)$ \\
\hline & \multicolumn{6}{|c|}{ Hygromycin $\left(\mathrm{mg} \cdot \mathrm{L}^{-1}\right)$} \\
\hline Explants $^{\mathrm{z}}$ & 0 & 5 & 10 & 20 & 50 & \\
\hline \multicolumn{7}{|l|}{ Survived (\%) } \\
\hline Cotyledon & $25(100)^{\mathrm{y}}$ & $21(84)$ & $0(0)$ & $0(0)$ & $0(0)$ & \\
\hline Hypocotyl & $25(100)$ & $17(68)$ & $0(0)$ & $0(0)$ & $0(0)$ & \\
\hline \multicolumn{7}{|c|}{ Regenerated (\%) } \\
\hline Cotyledon & $25(100)^{x}$ & $0(0)$ & $0(0)$ & $0(0)$ & $0(0)$ & \\
\hline Hypocotyl & $25(100)$ & $0(0)$ & $0(0)$ & $0(0)$ & $0(0)$ & \\
\hline
\end{tabular}

zTwenty-five explants were tested on MS medium supplemented with indolacetic acid $\left(0.2 \mathrm{mg} \cdot 1^{-1}\right) \mathrm{and}$ BAP $\left(2.0 \mathrm{mg} \mathrm{l}^{-1}\right)$ in each experiment.

${ }^{\mathrm{y}}$ Number of explants survived $(\%)$.

${ }^{\mathrm{x}}$ Number of explants regenerated (\%).
Biosciences, Buckinghamshire, UK) and hybridization was carried out for $20 \mathrm{~h}$ at 65 ${ }^{\circ} \mathrm{C}$ in Rapid-hyb buffer with $\alpha{ }^{32} \mathrm{P}$-labeled probe. The probe DNA consisted of part of the $h p t$ coding region amplified from pCAMBIA1301 and labeled with $\left[\alpha-{ }^{32} \mathrm{P}\right] \mathrm{dCTP}$ using the Random Prime labeling system (Amersham Biosciences). After hybridization, membranes were rinsed with $1 \mathrm{X}$ SSPE, $0.2 \% \mathrm{SDS}$ at room temperature, and washed twice for $45 \mathrm{~min}$ each at $65{ }^{\circ} \mathrm{C}$ in $0.25 \mathrm{X}$ SSPE, $0.2 \%$ SDS. The filter was exposed at $-80{ }^{\circ} \mathrm{C}$ on Kodak XAR-5 film (Kodak, Windsor, $\mathrm{CO}$ ) with an intensifying screen.

Polymerase chain reaction analysis. Two primer sets were used on each DNA sample for amplification: 1) a 871-base pair (bp) fragment containing the uidA gene (forward: acg cgg tga tac ata tcc agc ca) and 2) a 412-bp fragment containing the hpt gene (forward: gaa gaa tct cgt get ttc ag; reverse: gtg tcg tcc atc aca gtt $t$ ). Polymerase chain reaction (PCR) was performed in the DNA Thermal Cycler (Perkin Elmer, Norwalk, CT) programmed for 30 cycles of $94{ }^{\circ} \mathrm{C}$ for $30 \mathrm{~s}, 60$ ${ }^{\circ} \mathrm{C}$ for $30 \mathrm{~s}$, and $72{ }^{\circ} \mathrm{C}$ for $60 \mathrm{~s}$. PCR products were resolved by agarose-gel electrophoresis.

\section{Results and Discussion}

Selection of selectable marker gene and plant explant. To find a suitable selectable marker gene/agent for pepper transformation, the regenerability of cotyledons was compared on medium containing various concentrations of kanamycin and hygromycin (Table 1). The explants were highly resistant to kanamycin; even $150 \mathrm{mg} \cdot \mathrm{L}^{-1}$ did not inhibit callus induction, and, at $100 \mathrm{mg} \cdot \mathrm{L}^{-1}$ kanamycin, over $80 \%$ of cotyledonary explants developed shoot buds. In contrast, the explants were highly sensitive to hygromycin with complete inhibition of callus induction and bud regeneration at $10 \mathrm{mg} \cdot \mathrm{L}^{-1}$ and $5 \mathrm{mg} \cdot \mathrm{L}^{-1}$, respectively.

Several crops are known to be resistant to kanamycin so the $n p t \mathrm{II} /$ kanamycin system is not applicable for the selection of the gaa ggt tat ctc tat gaa ctg tgc gtc; reverse: aag 
transformed cells. In pepper, despite the report that the system resulted in an unacceptably high proportion of escapes (Mihalka et al., 2000), the nptII gene has been mainly used as a selection marker to screen transgenic pepper cells (Lee et al., 2004; Li et al., 2003; Ochoa-Alejo and Ramirez-Malagon., 2001). Our results also show that pepper cells exhibit an intrinsic resistance to kanamycin. Thus, application of kanamycin might not be enough to screen pepper cells carrying the nptII gene during the transformation procedure.

The $h p t$ /hygromycin system has allowed stringent selection of transformed events in cassava (Zhang et al., 2000), sweetpotato (Kimura et al., 2001), cotton (Rajasekaran et al., 2000), and cucumber (Nishibayashi et al., 1996). Therefore, the $h p t /$ hygromycin selection strategy was chosen for pepper transformation in a further experiment. On the basis of the present study, $20 \mathrm{mg} \cdot \mathrm{L}^{-1}$ hygromycin was used at the callus induction stage and $10 \mathrm{mg} \cdot \mathrm{L}^{-1}$ at the regeneration stage, respectively, to select transformed callus and regenerate transgenic shoots.

Transformation of pepper explants. Cotyledonary explants were infected with Agrobacterium cells harboring pCAMBIA1301 (Fig. 1A). After three to four subcultures of explants onto callus induction medium containing hygromycin, the hygromycin-resistant calli were clearly identified (Fig. 1B) and the rate of callus induction was $\approx 20 \%$. The explant of the wild type was highly sensitive to hygromycin so that it was necrotized and finally died within three continuous subcultures. Only green calli survived on hygromycin were transferred to the regeneration medium containing hygromycin and within three to four continuous subcultures, adventitious buds developed from green sectors of the calli (Fig. 1D). The hygromycin-resistant shoots were transferred to rooting medium; 1 month later in the rooting medium, nine independent plants were produced (Fig. 1E).
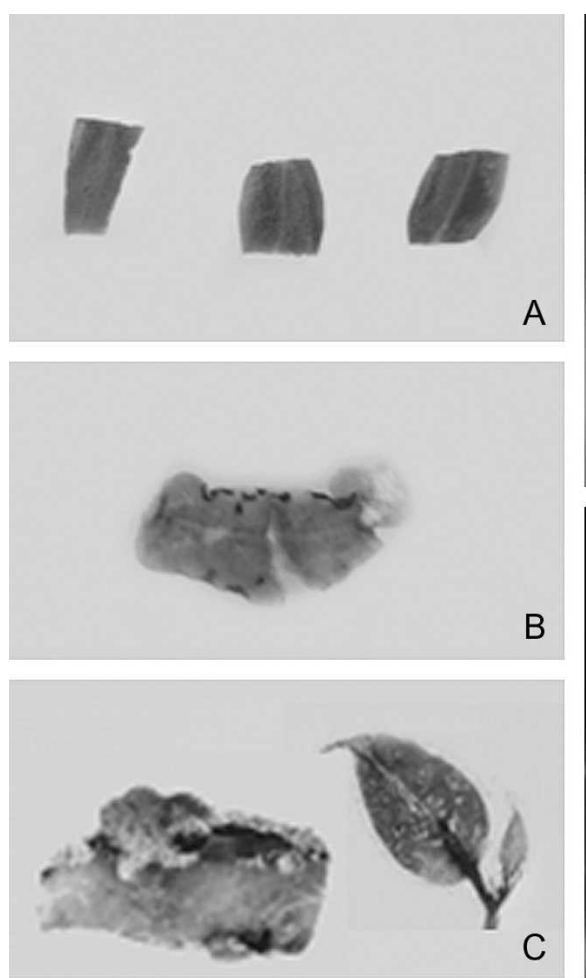

c

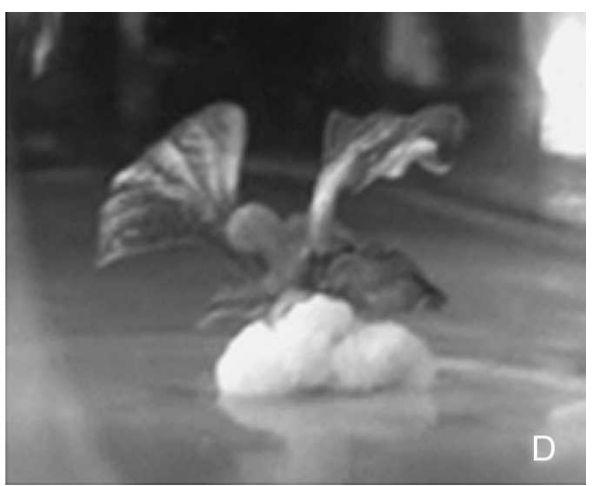

B

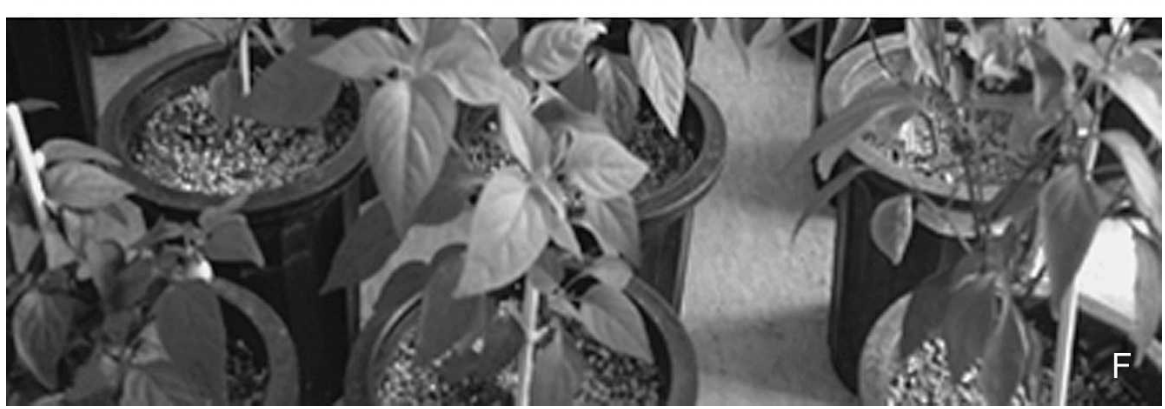

Fig. 1. Steps for the development of transgenic pepper plants. (A) Cotyledonary explants cocultivated with A. tumefaciens containing pCAMBIA 1301; (B) development of calli from the cutting edge of the infected explant on medium containing hygromycin $\left(20 \mathrm{mg} \mathrm{l}^{-1}\right) ;(\mathbf{C})$ localization of histochemical GUS activity in developing calli and regenerated shoot; (D) shoot regenerated from the callus; (E) rooting of the regenerated pepper shoot; $(\mathbf{F})$ pepper plants acclimated in pots.
In the greenhouse, these plants were phenotypically normal (Fig. 1F) and seeds were obtained by self-pollination.

The time required from infection to transfer of plants to the green house was 5 to 7 months. With nine transgenic plants from $\approx 1500$ infected explants, the transformation frequency was $\approx 0.6 \%$. Although the timeframe was similar to that reported by Lee et al. (2004), this transformation frequency with $h p t$ /hygromycin is higher than the $0.03 \%$ to $0.19 \%$ reported for $n p t \mathrm{II} /$ kanamycin in that experiment. We found that the higher transformation frequency is attributable to the use of a stringent selection system resulting in the growth of transformed cells from the early stage. Thus, a pepper transformation system using the $h p t /$ hygromycin selection strategy has the potential to allow fewer escapes and require less effort in terms of time, cost, and labor. Further studies are under progress to increase transformation efficiency of pepper in combination with the $h p t /$ hygromycin selection system. Development of an advanced propagation technology such as somatic embryogenesis will assist in more efficient genetic transformation of hot pepper for biotechnological purpose.

GUS expression in the transgenic peppers. GUS activity was measured histochemically as well as quantitatively in the primary transgenic pepper plants. Histochemical analysis showed that the uidA gene was constitutively expressed in the primary transgenic event (Fig. 1C) and in all organs, including leaves, floral organ, root, and fruit at different levels (Fig. 2A). This was also supported by fluorometric GUS assays that measured quantitatively in flower, shoot

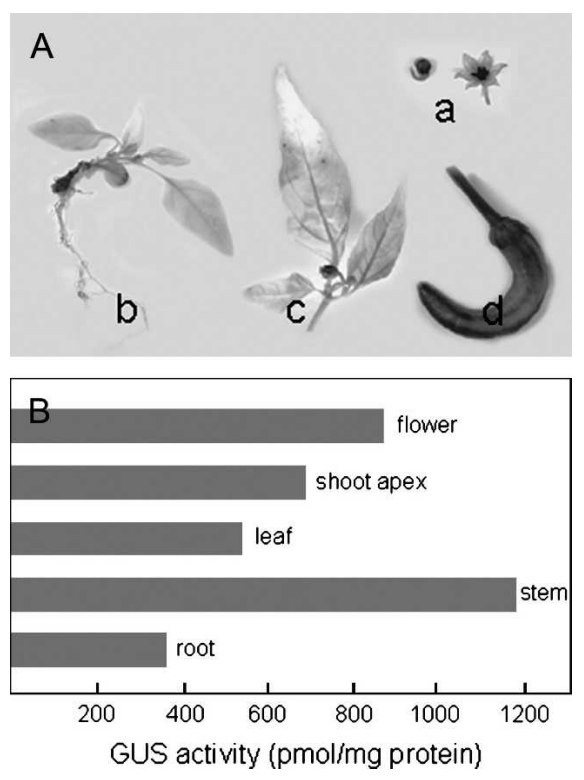

Fig. 2. GUS activity in the primary transgenic peppers. Quantitative assays for GUS-specific activity conducted (A) in situ or (B) in extracts of various tissues from a transgenic pepper that carry the uidA reporter gene. (a) Flower; (b) plantlet with root; (c) leaves; (d) fruit. 
apex, leaves, stem, and root (Fig. 2B). The results indicate that the uidA gene was stably expressed in the transgenic pepper.

To observe the GUS activity in the progenies, 21 seeds obtained from a $\mathrm{T}_{0}$ transgenic pepper (no. 2) and the wild type were germinated on MS medium containing 20 $\mathrm{mg} \cdot \mathrm{L}^{-1}$ hygromycin. After 2 weeks, all seedlings were evaluated and stained in X-gluc solution for GUS activity. In the transgenic line, 15 of 21 seedlings exhibited resistance to the hygromycin as well as GUS activity, whereas six seedlings did not show either hygromycin resistance or GUS activity (Fig. 3). Wild-type seedlings showed severely retarded growth in the selection medium and eventually died. This result represented that both uidA and hpt genes are transmitted to the next generation and expressed in the progeny.

Segregation analysis of transgenic pepper lines. To determine whether the transgenes were stably inherited in the next generation, self-pollinated seeds harvested from nine primary transgenic pepper lines were evaluated for the resistance to $20 \mathrm{mg} \cdot \mathrm{L}^{-1}$ hygromycin (Table 2). Hygromycin-resistant and susceptible seedlings were clearly identified within 1 week. A segregation ratio of $3: 1$ was observed in seven of the nine lines, representing a single functional hpt gene locus in the pepper genome. $\chi^{2}$ analysis indicated a $3: 1$ segregation for the $h p t$ gene, a ratio that suggested Mendelian segregation of a single dominant gene. The results indicate that transgenic pepper plants produced by Agrobacterium-mediated transformation were genetically and phenotypically stable in advanced generations. However, a non-Mendelian inheritance pattern was also observed in lines 6 and 7, of which the segregation ratio between resistant and sensitive was 10:54 and $82: 12$, respectively. For line 6 , seed development might not be uniform or the introduced transgene might not be functionally expressed. Although we did not carry out
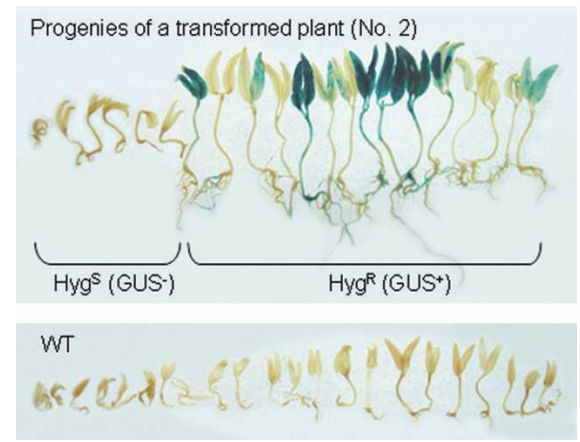

Fig. 3. Segregation of hygromycin resistance and GUS activity in the transgenic progeny. After germination of 21 seeds harvested from $\mathrm{T}_{0}$ plant (no. 2), 15 seedlings were resistant to hygromycin and GUS positive; the remaining six were not hygromycin-resistant or GUSpositive. As a control, seedlings germinated from wild-type (WT) seeds showed stopping growth, no GUS activity, and no hygromycin resistance.

Table 2. Segregation of hygromycin resistance in the progeny of primary transgenic peppers.

\begin{tabular}{lccccc}
\hline Line & No. $_{\text {germinated }}{ }^{\mathrm{z}}$ & ${\text { Resistant }(\%)^{\mathrm{y}}}$ & Sensitive (\%) $^{\mathrm{x}}$ & $\chi^{2 \mathrm{w}}$ & Ratio $^{\mathrm{v}}$ \\
\hline $\mathrm{WT}$ & 60 & $0(0.00)$ & $60(100)$ & $\overline{-}$ & - \\
1 & 82 & $64(78.0)$ & $18(22.0)$ & 0.40 & $3: 1$ \\
2 & 99 & $76(76.7)$ & $23(23.2)$ & 0.01 & $3: 1$ \\
3 & 111 & $81(72.9)$ & $30(27.1)$ & 0.24 & $3: 1$ \\
4 & 62 & $48(77.4)$ & $14(22.6)$ & 0.19 & $3: 1$ \\
5 & 62 & $50(80.6)$ & $12(19.4)$ & 1.05 & $3: 1$ \\
6 & 64 & $10(15.6)$ & $54(84.4)$ & 120.0 & - \\
7 & 94 & $82(87.2)$ & $12(12.8)$ & 7.50 & - \\
8 & 62 & $48(77.4)$ & $14(22.6)$ & 0.19 & $3: 1$ \\
9 & 80 & $58(72.5)$ & $22(27.5)$ & 0.26 & $3: 1$ \\
\hline
\end{tabular}

${ }^{\mathrm{z}}$ Seeds were germinated on MS medium containing $20 \mathrm{mg} \cdot \mathrm{L}^{-1}$ hygromycin; germination rate $>97 \%$.

${ }^{\mathrm{y}}$ Seedlings [no. (\%)] survived on medium containing hygromycin $\left(20 \mathrm{mg} \cdot \mathrm{L}^{-1}\right)$.

${ }^{x}$ Seedlings [no. (\%)] sensitive on medium containing hygromycin $\left(20 \mathrm{mg} \cdot \mathrm{L}^{-1}\right)$.

wSignificantly different at the $5 \%$ level.

"Ratio of resistant versus sensitive seedlings on hygromycin.

Southern blot analysis with line 7 , the introduced transgene might be integrated at more than two transgenic loci in the pepper genome. However, this phenomenon is commonly observed in plant transformation research (Christou et al., 1989; De Block et al., 1984).

Molecular characterization of transgenic plants. Stable integration of the transgenes was further investigated in the primary and $\mathrm{T}_{1}$ progeny of transgenic peppers. Southern blot analysis was conducted with the genomic DNA isolated from the primary transgenic lines 2 and 3, their progenies, and the wild type as a negative control. The genomic DNAs were digested with HindIII and hybridized with a probe consisting of the hpt gene. DNA from the wild-type (nontransformed) plant showed no hybridization signal to the probe DNA (Fig. 4A). Each primary transgenic line showed a single band with a different band pattern, indicating that these two lines represented independent events. Their respective $T_{1}$ progeny showed a single band with the same band mobility as the parent plant, indicating that the introduced transgene had been successfully transmitted to the progeny without modification. Because the T-DNA of pCAMBIA1301 has a unique HindIII site, the result also represents that a single copy of the transgene was integrated into the pepper genome.

To confirm that the introduced transgene was stably expressed in the transgenic peppers, Northern blot analysis was carried out with the primary transgenic lines 2 and 3, their progenies, and the wild type. The isolated total RNA was hybridized with $h p t$ probe DNA. At the mRNA level, the introduced transgene was transcriptionally expressed in the two primary transgenic lines as well as their $T_{1}$ progenies, whereas no signal was detected in the wild type (Fig. 4B). This indicates that the introduced transgenes were stably expressed in the progeny. In general, a single copy of T-DNA insertion results in high levels of transgene expression, whereas multiple copies of transgene expressions may lead to suppression of the chimeric gene in some cases (Van der Krol et al., 1990).

Inheritance of transgenes in an advanced generation $\left(T_{2}\right)$. PCR analysis was performed
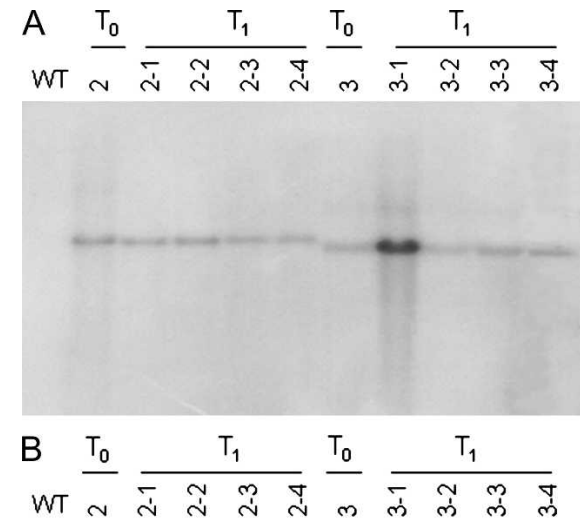

Fig. 4. Southern and Northern blot analyses. (A) Southern blot analysis of two $\mathrm{T}_{0}$ transgenic lines and their $T_{1}$ progenies. DNA samples from two transgenic lines and an untransformed pepper plant (WT) were digested with Hind III, and the resulting fragments were resolved by electrophoresis and transferred to a membrane. The membrane was hybridized with a ${ }^{32} \mathrm{P}$ labeled probe DNA corresponding with the hpt coding region. (B) Northern blot analysis of two transgenic pepper lines. WT, wild type; lane 2, line 2 plants $\left(\mathrm{T}_{0}\right)$; lanes $3-6, \mathrm{~T}_{1}$ progenies from line 2 ; lane 7 , line 3 plants $\left(\mathrm{T}_{0}\right)$; lanes $8-11, \mathrm{~T}_{1}$ progenies from line 3 . The membrane was hybridized with a ${ }^{32} \mathrm{P}$-labeled hpt.

on the two independent $\mathrm{T}_{1}$ plants and their progenies (Fig. 5). Both the uidA and hpt genes introduced to the pepper genome were revealed in the $T_{1}$ and $T_{2}$ generations of transgenic lines 2 and 3 , indicating that the transgenes were stably transmitted.

We investigated whether both of the introduced transgenes, hpt and uidA, were expressed in the $T_{2}$ generation without segregating or silencing (Table 3 ). Twenty $\mathrm{T}_{2}$ seeds from lines 2 and 3 were germinated on hygromycin-containing medium and the seedlings were transplanted into pots. Leaf discs were incubated in $100 \mathrm{mg} \cdot \mathrm{L}^{-1}$ hygromycin to test for hygromycin resistance and in X-gluc for histochemical assay of uidA gene expression. All $\mathrm{T}_{2}$ progenies were functionally resistant to hygromycin, whereas nontransgenic plants were 


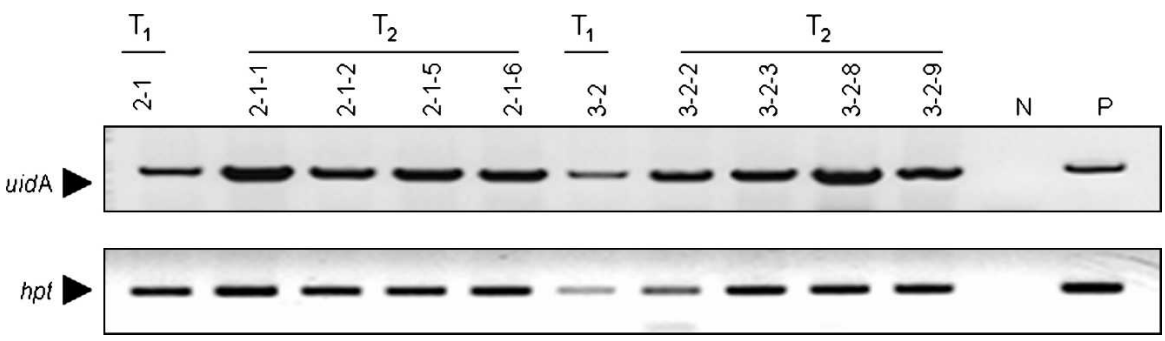

Fig. 5. Transmission of uidA (upper) and hpt (lower) genes to $\mathrm{T}_{2}$ progenies determined by polymerase chain reaction analysis in two independent transgenic pepper lines. 2-1, $\mathrm{T}_{1}$ transgenic pepper; 2-1-1, 2, $5,6, \mathrm{~T}_{2}$ transgenic progenies from transgenic line 2-1;3-2, $\mathrm{T}_{1}$ transgenic pepper; $3-2-2,3,8,9, \mathrm{~T}_{2}$ transgenic progenies from transgenic line 3-2; WT, nontransgenic pepper as a negative control; P, pCAMBIA1301 as a positive control.

Table 3. Inheritance and functional activity of transgenes (hpt and uidA) in homozygous transgenic plants.

\begin{tabular}{|c|c|c|c|c|}
\hline \multirow[b]{2}{*}{ Line } & \multirow[b]{2}{*}{ Homozygosity } & \multicolumn{2}{|c|}{ Functional activity } & \multirow{2}{*}{$\begin{array}{c}\mathrm{PCR}^{\mathrm{w}} \\
\text { hpt/uidA }\end{array}$} \\
\hline & & $\mathrm{HPT}^{\mathrm{y}}$ & GUS $^{x}$ & \\
\hline$\overline{\mathrm{WT}}$ & - & $\mathrm{S}$ & - & $-1-$ \\
\hline $2-1$ & NS & $\mathrm{R}$ & + & $+/+$ \\
\hline $2-1-1$ & NS & $\mathrm{R}$ & + & $+/+$ \\
\hline $2-1-2$ & NS & $\mathrm{R}$ & + & $+/+$ \\
\hline $2-1-5$ & NS & $\mathrm{R}$ & + & $+/+$ \\
\hline $2-1-6$ & NS & $\mathrm{R}$ & + & $+/+$ \\
\hline $3-2$ & NS & $\mathrm{R}$ & + & $+/+$ \\
\hline $3-2-2$ & NS & $\mathrm{R}$ & + & $+/+$ \\
\hline $3-2-3$ & NS & $\mathrm{R}$ & + & $+/+$ \\
\hline $3-2-8$ & NS & $\mathrm{R}$ & + & $+/+$ \\
\hline $3-2-9$ & NS & $\mathrm{R}$ & + & $+/+$ \\
\hline
\end{tabular}

Homogeneous transgenic pepper lines were confirmed by use of the hygromycin test; GUS histochemical assay and polymerase chain reaction in $\mathrm{T}_{1}$ and their $\mathrm{T}_{2}$ progenies.

${ }^{2}$ Heterogeneity of hygromycin resistance of seedlings on hygromycin $\left(20 \mathrm{mg} \cdot \mathrm{L}^{-1}\right)$; NS, no segregation of hygromycin resistance in the progenies.

${ }^{y}$ Leaf discs tested for the resistance to hygromycin $\left(100 \mathrm{mg} \cdot \mathrm{L}^{-1}\right)$ in distilled water; $\mathrm{S}$, sensitive; $\mathrm{R}$, resistant.

${ }^{x}$ Leaf discs tested for GUS activity by histochemical staining.

"Transgene inheritance in transgenic progenies was investigated by polymerase chain reaction (PCR) with $h p t$ and uidA primer sets.

bleached or necrotized. In the histochemical GUS assay, leaf samples from all $\mathrm{T}_{2}$ progenies, which had hygromycin resistance, showed GUS activity. Thus, the data demonstrate that $h p t$ and uidA genes were transmitted and stably expressed in the $\mathrm{T}_{2}$ progenies of the two independent transgenic pepper lines.

To examine the reliability of $h p t /$ hygromycin system in pepper transformation, the sensitivity of pepper explants to hygromycin was compared in transgenic and nontransgenic plants by measuring fresh weight of hypocotyl explants (Fig. 6). With an increasing hygromycin concentration, the fresh weight of hypocotyls was dramatically reduced in wild type. Although untransformed pepper cells were highly sensitive to hygromycin, calli with developing buds were induced in transgenic explants. At over $10 \mathrm{mg} \cdot \mathrm{L}^{-1}$ hygromycin, adventitious healthy shoots were produced only in hypocotyl explants from transgenic plants.
A
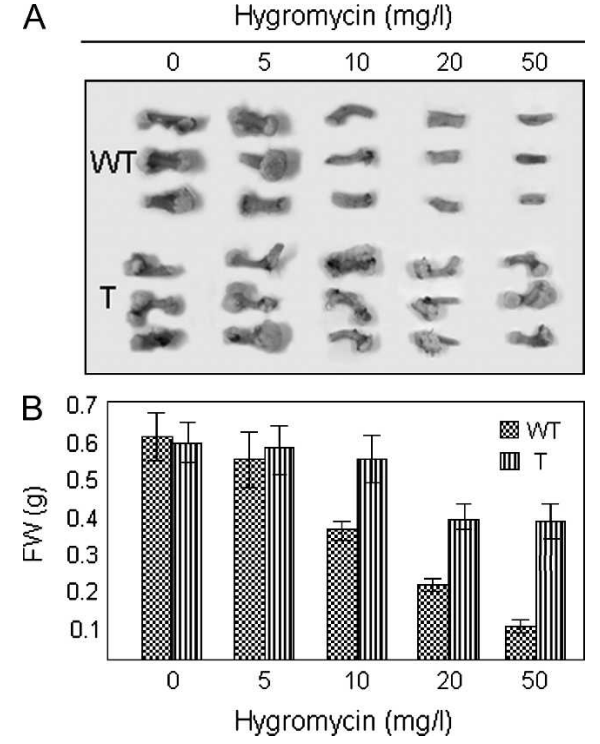

Fig. 6. Growth of hypocotyl explants from nontransformed (WT) and transformed (T) peppers carrying the hpt gene on medium containing 0 to $50 \mathrm{mg} \cdot \mathrm{L}^{-1}$ hygromycin. (A) Callus and shoot formation. (B) Average of fresh weight of 60 explants after 3 weeks of incubation. The bars indicate $\mathrm{SE}$.

In conclusion, we report the development of a reliable protocol for production of transselection strategy. The selection strategy is critical for improving transformation efficiency of pepper. Although the nptII gene was successfully implemented in Agrobacterium-mediated transformation, the npt II/ kanamycin selection strategy requires an extended culture in vitro and labor/cost to screen the escapes of nontransformed events. The hpt/hygromycin selection system allows stringent selection of transgenic pepper plants to eliminate or reduce the escape of untransformed or silenced transgenic pepper plants. Using $h p t$ /hygromycin selection strategy, we confirmed stable inheritance of the introduced transgenes into subsequent generations and stable expression of the transgenes in the progenies. Therefore, the $h p t$ marker system described in this study demonstrates its use for an effective transformation of pepper. genic pepper plants with the $h p t$ /hygromycin

\section{Literature Cited}

Agrawal, S., N. Chandra, and S.L. Kothari. 1989 Plant regeneration in tissue cultures of pepper (Capsicum annuum L. cv Mathania). Plant Cell Tiss. Org. Cult. 16:47-55.

Binzel, M.L., N. Sankhla, S. Joshi, and D. Sankhla. 1996. Induction of somatic embryogenesis and plant regeneration in pepper (Capsicum annuum L.). Plant Cell Rep. 15:536-540.

Birch, R.G. 1997. Plant transformation: Problems and strategies for practical application. Ann. Rev. Plant Physiol. Plant Mol. Biol. 48:297-326.

Bradford, M.M. 1976. A rapid and sensitive method for the quantitation of microgram quantities of protein utilizing the principle of protein-dye binding. Anal. Biochem. 72:248-254.

Cai, W.Q., R.-X. Fang, H.-S. Shang, X. Wang, F.-L. Zhang, Y.-R. Li, J.-C. Zhang, X.-Y Cheng, G.-L. Wang, and K.-Q. Mang. 2003. Development of CMV- and TMV-resistant chili pepper: Field performance and biosafety assessment. Mol. Breed. 11:25-35.

Cai, W.Q., R.X. Fang, F.L. Zhang, J.C. Xhang, Z Chen, G.L. Wang, K.Q. Mang, H.S. Shang, X. Wang, and Y.R. Li. 2002. Virus-resistant chili pepper produced by Agrobacterium speciesmediated transformation, p. 563-578. In: Khachatourians, G., A. McHughen, R. Scorza, W-K. Nip, and Y.H. Hui (eds). Transgenic plants and crops. Marcel Dekker, New York.

Christou, P., W.F. Swain, N.S. Yang, and D.E. McCabe. 1989. Inheritance and expression of foreign genes in transgenic soybean plants. Proc. Natl. Acad. Sci. USA 86:7500-7504.

De Block, M., L. Herrera-Estrella, M. Van Montagu, J. Schell, and P. Zambryski. 1984. Expression of foreign genes in regenerated plants and their progeny. EMBO J. 3:16311689.

Dumas de Vaulx, R., D. Chambonnet, and E. Pochard. 1981. In vitro culture of pepper (Capsicum annuum L.) anther: High rate plant production from different genotype by $+35^{\circ} \mathrm{C}$ treatment. Agronomie 1:859-864.

Ebida, A. and C. Hu. 1993. In vitro morphogenetic responses and plant regeneration from pepper (Capsicum annuum L. cv Early California Wonder) seedling explants. Plant Cell Rep. 13:107-110.

Gunay, A.L. and P.S. Rao. 1978. In vitro plant regeneration from hypocotyls and cotyledon explants of red pepper (Capsicum). Plant Sci. Lett. 11:365-372.

Jefferson, R.A. 1987. Assaying chimeric genes in plants: The GUS gene fusion system. Plant Mol. Biol. Rep. 5:387-405.

Kimura, T., M. Otani, T. Noda, O. Ideta, T. Shimada, and A. Saito. 2001. Absence of amlyose in sweet potato [Ipomoea batatas (L.) Lam.] following the introduction of granule-bound starch synthase I cDNA. Plant Cell Rep. 20:663-666.

Lee, Y.H., H.S. Kim, J.Y. Kim, M. Jung, Y.S. Park, J.S. Lee, S.H. Choi, N.H. Her, J.H. Lee, N.I. Hyung, C.H. Lee, S.G. Yang, and C.H. Harn. 2004. A new selection method for pepper transformation: Callus-mediated shoot formation. Plant Cell Rep. 23:50-58.

Li, D., K. Zhao, B. Xie, B. Zhang, and K. Luo. 2003. Establishment of a highly efficient transformation system for pepper (Capsicum annuum L.). Plant Cell Rep. 21:785-788.

Liu, W., W.A. Parrott, D.F. Hildebrand, G.B. Collins, and E.G. Williams. 1990. Agrobacterium-induced gall formation in bell pepper (Capsicum annuum L.) and formation of shoot like structures expressing introduced genes. Plant Cell Rep. 9:360-364. 
Mihalka, V., M. Fari, A. Szasz, E. Balazs, and I. Nagy. 2000. Optimized protocols for efficient regeneration and gene transfer in pepper (Capsicum annuum L.). J. Plant Biotechnol. 2: 143-149.

Murashige, T. and F. Skoog. 1962. A revised medium for rapid growth and bioassay with tobacco tissue cultures. Physiol. Plant. 5:473479.

Nishibayashi, S., H. Kaneko, and T. Hayakawa. 1996. Transformation of cucumber (Cucumis sativus L.) plants using Agrobacterium tumefaciens and regeneration from hypocotyl explants. Plant Cell Rep. 15:809814.

Ochoa-Alejo, N. and R. Ramirez-Malagon. 2001. In vitro chili pepper biotechnology. In Vitro Cell. Dev. Biol. Plant 37:701-729.

Phillips, G.C. and J.F. Hubstenberger. 1985. Organogenesis in pepper tissue cultures. Plant Cell Tiss. Org. Cult. 4:261-269.
Rajasekaran, K., R.L. Hudspeth, J.W. Cary, D.M. Anderson, and T.E. Cleveland. 2000. High-frequency stable transformation of cotton (Gossypium hirsutum L.) by particle bombardment of embryogenic cell suspension cultures. Plant Cell Rep. 19: 539-545.

Shin, R., J.-H. Han, G.-J. Lee, and K.-H. Peak. 2002. The potential use of a viral coat protein gene as a transgene screening marker and multiple virus resistance of pepper plants coexpressing coat proteins of cucumber mosaic virus and tomato mosaic virus. Transgenic Res. 11:215-219.

Steintiz, B., S. Kusek, Y. Tabib, I. Paran, and A. Zelcer. 2003. Pepper (Capsicum annuum L.) regenerants obtained by direct somatic embryogenesis fail to develop a shoot. In Vitro Cell. Dev. Biol. Plant 39:296-303.

Van den Elzen, P., J. Townsend, K.Y. Lee, and J. Bedbrook. 1985. A chimeric hygromycin resis- tance gene as a selectable marker in plant cells. Plant Mol. Biol. 5:299-302.

Van der Krol, A.R., L.A. Mur, M. Beld, J.N.M. Mol, and A.R. Stuitje. 1990. Flavonoid genes in petunia: Addition of a limited number of gene copies may lead to a suppression of a gene expression. Plant Cell 2:291-299.

Walden, R. and R. Wingender. 1995. Gene-transfer and plant-regeneration techniques. Trend. Biotechnol. 13:324-331.

Wolf, D., T. Matzevitch, B. Steinitz, and A. Zelcer. 2001. Why is it difficult to obtain transgenic pepper plants? Acta Hort. 560:229-234.

Zhang, P., I. Potrykus, and J. Puonti-Kaerlas. 2000. Efficient production of transgenic cassava using negative and positive selection. Transgenic Res. 9:405-415.

Zhu, Y., W. Ou-Yang, Y. Zhang, and Z. Chen. 1996. Transgenic sweet pepper plants from Agrobacterium mediated transformation. Plant Cell Rep. 16:71-75. 